\title{
WEB-BASED APPLICATIONS IN TRANSDISCIPLINARY TEACHER EDUCATION
}

Katarína $\boldsymbol{S Z A R K} \boldsymbol{A}^{*}$, Univerzita J. Selyeho v Komárne, Slovenská republika Beáta BRESTENSKÁ, Univerzita Komenského v Bratislave, Slovenská republika

Zoltán $\boldsymbol{F E H E ́} \boldsymbol{R}$, Univerzita J. Selyeho v Komárne, Slovenská republika Ladislav JARUSKA, Univerzita J. Selyeho v Komárne, Slovenská republika György JUHÁSZ, Univerzita J. Selyeho v Komárne, Slovenská republika Anita TÓTH-BAKOS, Univerzita J. Selyeho v Komárne, Slovenská republika

Přijato: 17. 5. 2018 / Akceptováno: 1. 8. 2018

Typ článku: Výzkumný článek

DOI: $10.5507 /$ jtie. 2018.004

Abstract: The paper presents the outputs and results of the research project, the main purpose of which was to map the digital competences of the current generation of future teachers, to identify their attitudes to the current state of undergraduate teacher training with regard to digital technology implementation. In cluster analysis research, we have mapped student groups by their level of digital competences and the evaluation they assigned to teachers on the basis of which we identified areas of development that need to be given greater attention in the preparation of future teachers.

Key words: web-based applications, undergraduate teacher training, digital competencies of teacher, transdisciplinary teacher education.

\section{WEBOVÉ APLIKÁCIE V TRANSDISCIPLINÁRNEJ PRÍPRAVE BUDÚCICH UČITELOV}

Abstrakt: V prispevku prezentujeme výstupy a výsledky projektu, ktorého hlavným zámerom bolo zmapovat' digitálne kompetencie u súčasnej generácii budúcich učitel'ov, zistit' ich postoje na súčasný stav pregraduálnej prípravy učitelov vzhladom na integráciu digitálnych technológii. Vrámci výskumu prostrednictvom zhlukovej analýzy sme zmapovali skupiny študentov podla úrovne ovládania prvkov digitálnych kompetencii a podl'a hodnotenia, ktoré pridelili učitelom na základe ktorého sme detegovali oblasti rozvoja, ktorým treba venovat' väčšiu pozornost' pri príprave budúcich učitel’ov.

Klúčové slová: webové aplikácie, príprava budúcich učitel'ov, digitálne kompetencie učitel'a, transdisciplinárne vzdelávanie učitel'ov.

\footnotetext{
*Autor pro korespondenci: szarkak@ujs.sk
} 


\section{1 Úvod}

Problematika prípravy budúcich učitel'ov popri inovácii školského vzdelávania sa stáva čoraz viacej akútnou problematikou transdisciplinárnej prípravy budúcich učitel'ov. Hovoríme o transdisciplinárnej príprave budúcich učitel'ov, ked'že digitálna gramotnost' učitel'a je nadpredmetovou kompetenciou a v súčasnosti fundamentálnou požiadavkou na každého učitel'a v informačnej spoločnosti. Príprava učitel'ov na zmysluplné využívanie technológií v triede je ústredným problémom v oblasti vzdelávania v 21. storočí (Bolick, C., Berson, M., Coutts, C., \& Heinecke, W. , 2003). Učitelia musia byt' pripravení efektívne zapojit' svojich žiakov do digitálneho vzdelávacieho prostredia a v rámci neho viest' ich ako sa učit' a ako získané poznatky používat' pre svoj rozvoj a pre prax (UNESCO NA, 2012). Zahraničné štúdia odporúčajú a zdôvodňujú opodstatnenost' účasti digitálnych technológií a nástrojov on-line sveta v príprave budúcich učitel'ov, so zámerom zlepšit' učebný procese budúcich učitel'ov a profesionálne rozvíjat'ich poznatky a zručnosti v oblasti predmetovej didaktiky z hl'adiska aplikácie digitálnych prostriedkov do budúcej praxe (Albion, 2008). Poukazujú aj na potenciál vytvárania sietí medzi učitel'mi, študentmi a spoluúčast' na tvorbe učebného obsahu (Greenhow, 2007), čo je taktiež požiadavkou digitálnej spoločnosti.

Od budúcich učitel'ov sa očakáva, aby boli schopní používat' technológiu pre svoju produktivitu (napr. byt' „in“, teda súčast'ou digitálneho sveta prezentovaním rôznych obsahov), ale tiež aby boli schopní pripravit' efektívnu integráciu technológií do výučby. Avšak práve príprava zmysluplnej integrácie technológií absentuje v študijných programoch prípravy budúcich učitel'ov. V dôsledku toho absolventi pedagogických fakúlt majú len obmedzené a povrchné znalosti a zručnosti v oblasti aplikácie technológií do vzdelávania (Cantu, 2000).

\section{Súčasná situácia prípravy budúcich učitel’ov}

Súčasná situácia na Slovensku je taká, že záujem o učitel’ské povolanie rapídne klesá. Popritom nezaznamenávame zmeny samotnej prípravy budúcich učitel'ov orientované na zvyšovanie kvality vzdelávania v súlade očakávaniam informačnej spoločnosti. Svet poznania postupne vyrastajúcej „digitálnej generácie detí“ sa vel'mi mení a študijné programy prípravy budúcich učitel'ov na Slovensku žial' neodrážajú potrebné zmeny v rozvoji nových kompetencií učitel'a, aby vedel v meniacom sa svete poznania vzbudit' záujem a riadit' aktívny proces učenia sa žiaka (Brestenská, B. et al., 2014).

Na základe predchádzajúcich skúseností z projektov orientované na

- profesionálny rozvoj učitel'ov v oblasti implementácie IKT do vzdelávania (Infovek, IDeš, Modernizácia vzdelávacieho procesu na ZŠ a SŠ, Moderný učitel' a i.)

- prípravu budúcich učitel'ov, kde hlavným zámerom bolo prepojenie práce inovatívnych učitel'ov z praxe s didaktickou prípravou budúcich učitel'ov (Inkubátor inovatívnych učitel'ov prírodovedných predmetov na ZŠ a SŠ) (http://inkubatorucitelov.eskola.sk/, 2014)

sme sa rozhodli na Pedagogickej fakulte UJS v spolupráci Katedry didaktiky prírodných vied, psychológie a pedagogiky Prírodovedeckej fakulty UK v Bratislave realizovat' trojročný projekt (2016-2018) „Web-based aplikácie v transdisiplinárnom vzdelávaní budúcich učitel'ov“ pokračovat' v inovácii prípravy budúcich učitel'ov a prispôsobovaním ich prípravy požiadavkám digitálnej spoločnosti. 
Hlavnou ambíciou projektu je inovovat' vzdelávacie formy a metódy prípravy budúcich učitel'ov na PF UJS prostredníctvom web-based aplikácií.

\section{Web-based aplikácie vo vzdelávaní}

Webové aplikácie sú on-line programy bežiace prostredníctvom webových prehladávačov a použijúc http protokol, umožňujúc vytvorenie, editovanie, formátovanie, načítavanie (upload), stiahnutie (download), organizovanie, zdiel’anie (share) textového, audio-vizuálneho a rôznych d’alších foriem digitálneho obsahu. Webové aplikácie sa najčastejšie zobrazujú vo webovom prehliadači, avšak, existujú aj client-based aplikácie, kde malá čast' programu sa stiahne do užívatel'skej plochy, ale spracovanie sa vykonáva cez internet na externom serveri. V súčasnosti vel’a webových aplikácií má aj mobilnú aplikáciu, a tie mali v našich ciel’och výskumu pridanú hodnotu.

Heafner a Friedman (2008) vidia vel'kú výhodu webových aplikácií v tom, že používatelia (učitel', študent) môžu spolupracovat' na tvorbe digitálnych obsahov bez toho, aby museli pracovat' v komplikovanom jazyku HTML kódu. Podla Adcock a Bolick (2011) prostredníctvom l'ahko použitel'ného rozhrania WYSIWG (,what you see is what you get"), webové nástroje umožňujú študentom tvorit' svoje vzdelávacie obsahy $\mathrm{v}$ textovom, vizuálnom, zvukovom tvare $\mathrm{v}$ rôznych kontextoch, pretransformovat' tak svoje vedomosti do digitálneho prostredia. Grant a Mims (2009) zdôrazňujú využitel'nost' web-based aplikácií vo vzdelávaní a poukazujú na to, že obmedzenia webových aplikácií súvisiace s prístupom a finančnými nákladmi v súčasnosti sa vo vel'kej miere zní̌ili, čo umožňuje študentom použivat' širokú škálu webových aplikácií. Zároveň výhody webových aplikácií zo strany učitel'ov vysvetl'ujú ich l'ahkým prístupom, možnostou dostupnosti k rôznym obsahom, ako aj ich integráciou do vlastného on-line vzdelávacieho prostredia učitel’a, čo korešponduje s ideami konštruktivistického učenia.

\section{Charakteristika výskumných bádaní realizovaných $\mathrm{v}$ projekte a popis ich metód}

$\mathrm{V}$ rámci projektu výskum sa orientoval jednak na analýzu webových aplikácií a ich možnosti implementácie do pregraduálnej prípravy učitelov, po druhé na zmapovanie digitálnych kompetencií študentov a ich postoje na rozvíjanie digitálnych kompetencií v rámci štúdia.

\section{Analýza vybraných web-based aplikácii a ich implementácia do prípravy budúcich učitel'ov}

V rámci projektu sme sa sústredili hlavne na komerčne vyvinuté web-based aplikácie, ktoré majú v sebe aj výchovno-vzdelávací potenciál. Poskytovatelia viacerých takých webových aplikácií ponúkajú bezplatný prístup $\mathrm{k}$ svojmu online prostrediu a digitálnym kapacitám pre vzdelávacie účely.

Analýzu web-based aplikácií a ich možnosti implementácie do prípravy budúcich učitel'ov sme realizovali v troch etapách.

Pôvodne sme vychádzali z nami vytvorenej databázy 55 webových aplikácií, z ktorých tri časom sa stali neaktívne. Súbor zostávajúcich 52 web-based aplikácií sme zoskupili do deviatich kategórií. V prvej etape projektu v období júl-december 2016, riešitel'ský tím realizoval technicko-obsahovo-metodickú analýzu web-based aplikácií vhodných pre vzdelávanie a orientuje sa na pozitívne príklady zo zahraničia.

K analýze webových aplikácií sme vytvorili štruktúrovaný hodnotiaci/pozorovací prostriedok, v rámci ktorého sme zamerali kategórie hodnotenia na skúmanie technických, obsahovo-štrukturálnych a didaktických aspektov webových aplikácií. Pri technických 
aspektoch skúmame spúštanie, podporu, dostupnost' a bezpečnost' aplikácií. V prípade obsahu a štruktúry sledujeme jazyk prostredia resp. existenciu jazykových mutácií, možnost' exportovania vytvoreného obsahu, možnost' spracovania multimediálneho obsahu, priehl'adnost' a úroveň ovládania prostredia webovej aplikácie.

Z didaktického hl'adiska analyzujeme aplikácie na základe možnosti zaradenia do vyučovacieho procesu, podla etáp vyučovania. Ďalej ich hodnotíme, ako zohl'adňujú aktívnost' v učebných činnostiach, do akej mieri majú sociálny charakter v učebných činnostiach, či umožňujú bezprostrednú spätnú väzbu a nakoniec či webová aplikácia poskytuje aj metodickú podporu.

Výsledky našich analýz sme spracovali do grafickej podoby, ktoré sú dostupné na webovej stránke projektu (http://apps4teachers.ujs.sk ).

V druhej etape v období marec-október 2017 sme realizovali tvorbu užívatelských manuálov $\mathrm{k}$ vybraným webovým aplikáciám. $\mathrm{Z}$ celkového súboru $\mathrm{k}$ vybraným 17 -tim webovým aplikáciami sú vytvorené užívatel'ské manuály, spracované bud’ popisnou formou (pdf), alebo formou prezentácí spracované ako video manuály. Ked’že Univerzita J. Selyeho je jediná univerzita na Slovensku, kde sa vyučuje aj v jazyku mad’arskej národnostnej menšiny, našou snahou bola užívatel'ské manuály sprístupnit aj dvojjazyčne. Takto vytvorený súbor 32 užívatel'ských manuálov je dostupný pre širokú verejnost' užívatel'ov na webovej stránke projektu.

V tretej etape v období november 2017 - apríl 2018 sme realizovali tvorbu ukážkových modelov učebných on-line aktivít prostredníctvom vybraných web-based aplikácií a ich implementáciu do vyučovania niektorých existujúcich predmetov študijných programov, študijného odboru učitel'stvo akademických predmetov. V rámci 9 predmetov a prostredníctvom 13 ukážkových hodín boli webové aplikácie a ich možnosti využitia vo vzdelávacom procese 405 študentom prezentované.

\section{Pedagogický prieskum}

Analýzou web-based aplikácí sme paralelne realizovali zmapovanie digitálnych kompetencií budúcich učitel'ov. Ako výskumnú metódu sme použili opytovaciu metódu a ako výskumný nástroj sme použili dotazník. Položky reflektovali na učitel'ské kompetencie na základe očakávania digitálnej spoločnosti 21. storočia, ktoré boli prevzaté zo zoznamu na educatorstechnology.com (Educatorstechnology, online). Prostredníctvom dotazníka na základe sebareflexie respondentov sme chceli preskúmat' a zhodnotit' úroveň digitálnych kompetencií študentov učitel'ského smeru. Sebareflexia je v profesijnej činnosti učitel'a dôležitou podmienkou zdokonal'ovania vlastnej práce, umožní zhodnotit' seba samého. Sebareflexia má byt' dôležitou súčastou činnosti aj študenta - budúceho učitel'a $\mathrm{v}$ jeho príprave.

Dotazníky boli anonymné, získavali len základné sociometrické údaje o respondentovi: vek, pohlavie, študijný program. Zistovali sme názory študentov v dvoch oblastiach: prvá položka (P6) obsahuje d’alších 20 podpoložiek (P6.1 - P6.20) s tvrdeniami zistujúcimi ovládanie prvkov digitálnych kompetencií a v druhej položke (P7) je zaradených 17 (P7.1 - P7.17) tvrdení o používaní digitálnych technológií v súčasnej príprave učitel'ov. Všetky podpoložky boli uzavreté s možnost'ou výberu odpovede z pät'bodovej Likertovej škály, vyjadrujúc mieru resp. intenzitu hodnotenia a sebahodnotenia sledovaného javu, kde sila intenzity súhlasu s tvrdením stúpa od 1 po 5 .

Dotazníkový prieskum bol zrealizovaný priebehu zimného semestra v mesiacoch október, november akademického rok 2017/18. Do prieskumu boli zapojení 197 študentov učitel'ských študijných programov Univerzity J. Selyeho v Komárne a v medzinárodnej 
spolupráci sme zapojili 59 študentov Katedry chemie Př́rodovědeckej fakulty Univerzity Hradec Králové. Na zabezpečení prieskumu sa podiel’ali riešitelia projektu KEGA. Dotazníky boli distribuované osobne, bezprostredne nasledovalo vyplnenie dotazníkov a ich pozbieranie. Tento spôsob je doporučený práve $\mathrm{v}$ prípade skúmania názoru respondenta, výhodou je aj vysoká, prakticky $100 \%$-ná návratnost' dotazníkov. Následnej analýze sme podrobili spolu 256 dotazníkov. Dotazníky sme kontrolovali z hladiska korektnosti, boli vylúčené dotazníky v ktorých respondent neodpovedal, alebo vyplnil neserióznym spôsobom. Konečný počet dotazníkov na ktorých sa vykonali následné štatistické analýzy je 253.

Pri spracovaní dát dotazníka sme použili kategorizáciu a zhlukovú analýzu.

Kategorizácia bola uskutočnená v prípade jednotlivých položiek (P6 a P7). V prípade týchto dvoch položiek bola uskutočnená kategorizácia jednotlivých tvrdení, vytvorili sme 4 kategórie podpoložiek podla činností, ktoré súvisia s ovládaním prvkov digitálnych technológií. Takto vytvorené kategórie sme nazvali: obrázok a video, sociálne siete, online učebné materiály a ostatné.

Zhluková analýzy patrí medzi viacrozmerné štatistické metódy. Ciel’om metódy je priradit’ jednotky analýzy $\mathrm{k}$ vytvoreným skupinám na základe podobnosti. Zhluková analýza využíva rôzne algoritmy, metóda k-priemerov podobnost' určuje na základe vzdialenosti medzi jednotkami, a každú jednotku zaradí presne do jednej skupiny nazývaný zhluk, alebo klaster z vopred určenej množiny k-zhlukov (Nisbet, 2009). Ako výsledok získame model, ktorý určuje zaradenie jednotiek do jednotlivých zhlukov, a tiež centrálnu pozíciu (centroid) týchto zhlukov. Zhlukovú analýzu sme realizovali prostredníctvom programu Rapid Miner Studio (ver. 8.1, free editon).

\section{Výsledky štatistickej analýzy dotazníka}

V prípade vyhodnotenia výsledkov dotazníkového prieskumu je dôležité zdôraznit', že prieskum bol vykonaný len na určitej vzorke študentov, preto získané závery nemožno a nebudeme zovšeobecňovat'. Pri interpretácii získaných výsledkov berieme do úvahy skutočnost', že v prieskume použitou dotazníkovou metódou sme zist'ovali subjektívne názory a postoje respondentov $\mathrm{k}$ danej problematike (Chráska, 2016). Preto závery prezentujú aktuálny stav preskúmanej problematiky predovšetkým na našej univerzite z pohladu našich študentov.

Položka P6 bola zameraná na zist'ovanie digitálnej kompetencie študenta na základe sebareflexie. $\mathrm{V}$ položke $\mathrm{P} 7$ sme sa venovali problematike používania prvkov digitálnych technológií v príprave budúcich učitel'ov. Zaradenie podpoložiek P6.1-P6.20 a tiež P7.1-P7.17 (Tab. č. 1) do vytvorených kategórií je uvedené v predchádzajúcej časti. 


\begin{tabular}{|c|c|c|}
\hline Kategórie & $\begin{array}{c}\mathrm{P} 6 \\
\begin{array}{c}\text { Zaradenie digitálnych kompetencii śtudentov } \\
\text { pregraduálnej pripravy ućitel'ov }\end{array}\end{array}$ & $\begin{array}{c}\mathrm{P7} \\
\begin{array}{c}\text { Zaradenie digitálnych kompetencií pedagógov } \\
\text { pregraduálnej pripravy učitel'ov }\end{array}\end{array}$ \\
\hline obrázok a video & $\begin{array}{l}\text { P6.1, P6.4, P6.5, P6.6, P6.11 } \\
\text { Práca s audiovizuálnym obsahom: tvorba, } \\
\text { spracovanie a použivanie digitálneho obsahu: } \\
\text { zvuk, obrázok, video. }\end{array}$ & $\begin{array}{l}\text { P7.3, P7.4, P7.5, P7.9 } \\
\text { Využitie digitálnych obrázkov a videozáznamov pre } \\
\text { vzdelávacie účely, na upútanie pozornosti študentov na } \\
\text { vyučovacej hodine, použitie infografických prvkov a } \\
\text { video tutoriálov. }\end{array}$ \\
\hline sociálne siete & $\begin{array}{l}\text { P6.2, P6.3, P6.7, P6.8, P6.19 } \\
\text { Použivanie sociálnych sieti na komunikáciu } \\
\text { a spoluprácu, zdiel'anie obsahu. Social } \\
\text { bookmarking, platformy použitím blogov } \\
\text { a wiki, tvorba e-portfólia. }\end{array}$ & $\begin{array}{l}\text { P7.1, P7.2, P7.6, P7.7, P7.16 } \\
\text { Použivanie sociálnych sieti na komunikáciu a } \\
\text { zdielanie obsahu. Social bookmarking. Tvorba } \\
\text { spoločného platformu pre študentov, vytvorenie e- } \\
\text { portfólia. }\end{array}$ \\
\hline online uč.mat. & $\begin{array}{l}\text { P6.9, P6.12, P6.13, P6.14, P6.16 } \\
\text { Tvorba online digitálneho obsahu pre } \\
\text { vyučovanie, prezentácie. Ovládanie softvérov } \\
\text { na riadenie učebného procesu, hlasovacie } \\
\text { aplikácie a testovacie prostriedky. }\end{array}$ & $\begin{array}{l}\text { P7.8, P7.10, P7.11, P7.12, P7.13; } \\
\text { Tvorba online digitálneho obsahu pre vyučovanie. } \\
\text { Vytvorenie a sprostredkovanie online prezentácií } \\
\text { a učebných materiálov, použivanie prostriedkov } \\
\text { riadenia učebného procesu. }\end{array}$ \\
\hline ostatné & $\begin{array}{l}\text { P6.10, P6.15, P6.17, P6.18, P6.20 } \\
\text { Znalosti autorských práv a plagiátorstva, } \\
\text { kreatívne využitie digitálnych technológii, } \\
\text { časový manažment, poznámkové nálepky. }\end{array}$ & $\begin{array}{l}\text { P7.14, P7.15, P7.17; } \\
\text { Kreatívne využitie digitálnych technológii, časový } \\
\text { manažment. Autentický webový obsah. Poznámkové } \\
\text { nálepky. }\end{array}$ \\
\hline
\end{tabular}

Tab. č. 1: Zaradenie digitálnych kompetencií položiek P6 a P7

V položke P6 študenti vyjadrili svoju úroveň ovládania prvkov digitálnej kompetencie hodnotením od 1 do 5 . Ak sa podrobnejšie pozrieme na výsledky, môžeme zistit' značné rozdiely aj v rámci jednotlivých kategórií (Obr. č. 1).

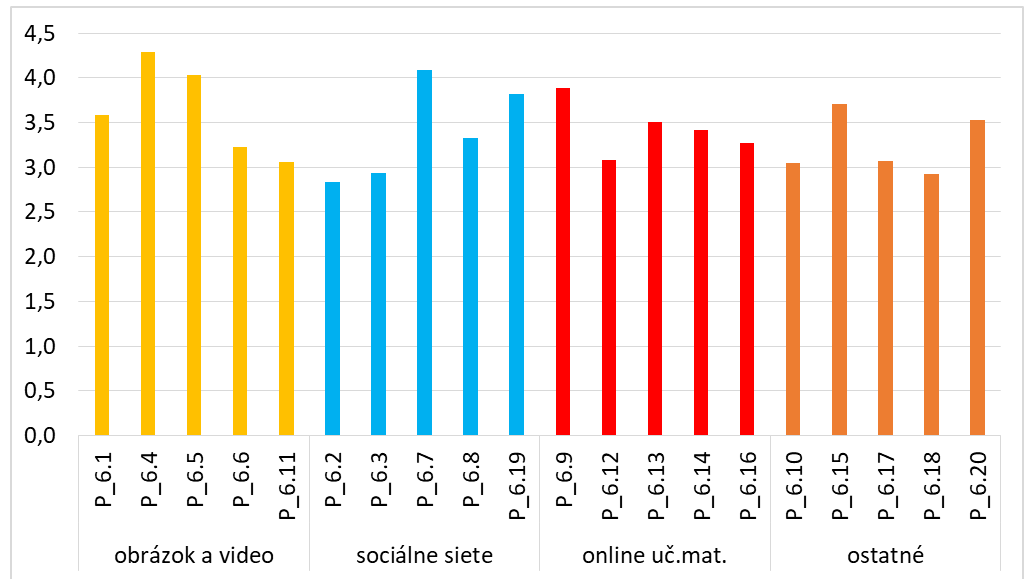

Obr. č. 1: Výsledky priemerných hodnôt sebareflexie DK študentov v položke P6.

V kategórii obrázok a video najvy̌šie priemerné hodnotenie 4,28 má využitie digitálnych obrázkov pre učebné účely (P6.4), pritom tvorba video tutoriálov (P6.11) je hodnotené priemerne 3,06 . V používaní sociálnych sietí je priemerne najvyššie hodnotené $(4,09)$ používanie sociálnej siete účelom kooperácie s kolegami (P6.7). Aj v rámci použivania sociálnych sietí majú študenti slabšie zručnosti, ako je používanie social bookmarking na zdielanie položiek (P6.2), alebo tvorba spoločného platformu využitím blogov a wiki (P6.3). V práci s online učebnými materiálmi študenti najviac 
ovládajú tvorbu online prezentácií (P6.9) s priemerom 3,89, v ostatných podpoložkách tejto kategórie študenti najviac uviedli hodnotenie 3 a 4. Najnižšie priemerné hodnotenie dosiahla podpoložka P6.12 zameraná na zabezpečenie online učebného obsahu.

Študenti v podpoložkách P7 hodnotili použivanie prvkov digitálnej technológie učitel'mi $\mathrm{v}$ rámci vysokoškolského štúdia na stupnici od 1 do 5 . V rámci niektorých podpoložkách (P 7.1 - P 7.17) kategórií môžeme zistit' väčšie rozdiely v priemernom hodnotení (Obr. č. 2).

V kategórii obrázok a video najvy̌šie priemerné hodnotenie 4,08 má využitie digitálnych obrázkov pre vzdelávacie účely (P7.3). Využitie digitálnych obrázkov získalo najvyššie hodnotenie aj v celkovom porovnaní. V používaní sociálnych sietí je priemerne najvyššie hodnotené používanie sociálnej siete účelom kooperácie so študentmi (P7.6) $\mathrm{s}$ výsledkom 3,74 . V práci $\mathrm{s}$ online učebnými materiálmi dostalo najvyššie bodové hodnotenie s priemerom 3,74 podpoložka $\mathrm{P} 7.10$, zabezpečenie online učebného materiálu pre vyučovanie.

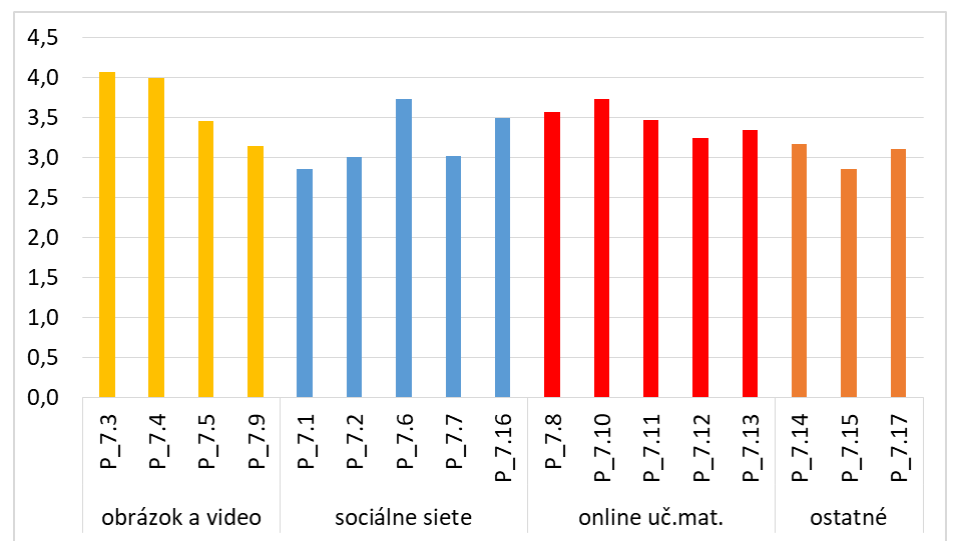

Obr. č. 2: Výsledky priemerné hodnotenia DK pedagógov v položke P7.

Ciel’om štatistickej analýzy zhlukovou analýzou je identifikácia takých skupín študentov, v ktorých sú zaradené jednotky navzájom podobné, teda majú podobné výsledky v uvedených kategóriách. Chceme zistit', aké skupiny študentov vieme vytvorit' podla úrovne ovládania prvkov digitálnych kompetencií, ktoré sme podrobne skúmali analýzou položky P6.

Zhlukovú analýzu sme uskutočnili na priemerných hodnotách vypočítaných $\mathrm{z}$ hodnotenia podpoložiek zaradených do štyroch vytvorených kategórií. Výsledkom analýzy je tabul'ka centroidov. Sú to hodnoty, ktoré udávajú priemernú hodnotu danej kategórie $\mathrm{v}$ zhluku, teda $\mathrm{v}$ našom prípade pre každý zhluk máme výsledok študenta a jeho priemerné hodnotenie $\mathrm{v}$ ovládaní práce $\mathrm{s}$ obrázkami a videom, $\mathrm{v}$ používaní sociálnych sietí, $\mathrm{v}$ tvorbe online učebných materiálov a v kategórii ostatných digitálnych kompetencií v prípade položky P6, a v položke P7 študenti hodnotili činnost' učitel'ov v súvislosti s použivaním prvkov digitálnej technológie vo vyučovaní. Výsledkom analýzy je identifikácia štyroch zhlukov spolu s tabul'kami centroidov pre položky P6 a P7. 


\begin{tabular}{|l|c|c|c|c|c|c|c|c|}
\hline \multirow{2}{*}{ Kategórie } & \multicolumn{4}{|c|}{ P6 } & \multicolumn{4}{c|}{ P7 } \\
\cline { 2 - 10 } & zhluk_0 & zhluk_1 & zhluk_2 & zhluk_3 & zhluk_0 & zhluk_1 & zhluk_2 & zhluk_3 \\
\hline obrázok a video & 3,82 & 4,25 & 3,19 & 2,93 & 3,81 & 3,42 & 4,19 & 2,56 \\
\hline sociálne siete & 3,52 & 4,22 & 3,13 & 2,29 & 2,77 & 3,22 & 3,79 & 2,33 \\
\hline online uč.mat. & 3,63 & 4,31 & 3,04 & 2,20 & 3,51 & 3,21 & 4,10 & 2,25 \\
\hline ostatné & 3,43 & 4,08 & 2,92 & 2,08 & 2,31 & 3,27 & 3,67 & 1,80 \\
\hline pomer jednotiek & $44,7 \%$ & $18,2 \%$ & $25,3 \%$ & $11,9 \%$ & $20,6 \%$ & $33,1 \%$ & $35,1 \%$ & $11,3 \%$ \\
\hline
\end{tabular}

Tab. č. 2: Hodnoty centroidov zhlukovej analýzy položky P6 a P7.

V časti P6 tabul'ky (Tab. č. 2) do zhluku 1 patria študenti, ktorí hodnotili svoje digitálne kompetencie $\mathrm{v}$ každej skúmanej oblasti najlepšie, všetky priemery sú nad hodnotou 4,0 . Do tejto skupiny patrí $18,2 \%$ študentov. Zhluk 0 a zhluk 2 predstavujú študentov s kompetenciami na strednej úrovni, ich priemerné hodnotenie je medzi 3,82 a 3,43 resp. 3,19 a 2,92. Zhluk 0 tvorí najpočetnejšiu skupinu študentov, analýza zaradila do tohto zhluku 44,7\% jednotiek. Do zhluku 2 bolo zaradených $25,3 \%$ študentov. Zhluk 3 tvoria študenti s najhorším hodnotením, vo všetkých štyroch kategóriách majú priemerné hodnotenie pod 3,0. Sem patrí 11,9\% analyzovaných študentov.

$\mathrm{V}$ časti P7 tabul'ky (Tab. č. 2) do jednotlivých zhlukov aj v tomto prípade sú zaradení študenti na základe hodnotenia, ktoré pridelili učitel’om. Do skupiny s najlepším hodnotením patria študenti, ktorí svojich vysokoškolských učitel’ov hodnotili v používaní digitálnych obrázkov a videozáznamu priemerne 4,19 , a v zabezpečení online učebných materiálov pre potreby vyučovania priemerne 4,10 . Títo študenti uviedli najvyššie hodnotenie aj v používaní sociálnej siete pre kooperáciu so študentmi s priemerom 3,79 a v ovládaní ostatných prvkov digitálnej kompetencie s priemerom 3,67. Tento názor zdiel'a $35,1 \%$ respondentov a tvoria zhluk 2 . Zhluk 0 a zhluk 1 predstavuje názor $53,7 \%$ študentov, ktorí hodnotili činnost' učitel'ov na strednej úrovni. Zhluková analýza $\mathrm{v}$ tejto strednej skupine identifikovala dva zhluky ktoré sa prekrývajú. V zhluku 1 študenti hodnotili učitel'ov nad priemerom 3,2 vo všetkých štyroch kategóriách digitálnej kompetencie. V zhluku 0 sú zaradený študenti, ktorí používanie digitálnych obrázkov a video materiálu a tiež zabezpečenie učiva s online učebným materiálom hodnotili vyššie (3,8 resp. 3,5), ale majú názor, že ich učitelia zaostávajú v používaní sociálnych sietí a v ostatných kompetenciách. Podl'a názoru $11,3 \%$ študentov ich učitelia nepoužívajú digitálnu technológiu pre potreby vyučovania na dostatočnej úrovni. Zhluk 3 tvoria študenti, ktorí hodnotili činnost' svojich učitel'ov väčšinou záporne s priemerom pod 2,56 vo všetkých štyroch kategóriách.

Výsledok zhlukovej analýzy vieme zobrazit' pomocou bodového grafu $(O b r . \check{c} .3$ a $O b r . \check{c} .4)$, čo vel'mi prehl'adne znázorňuje jednotlivé zhluky. Každý bod znamená jedného študenta, farba resp. tvar jednotky označuje priradenie k zhluku. Zhluky nie sú jednoznačne ohraničené, ked'že obrázok 7 ukazuje výsledok zhlukovej analýzy v štyroch kategóriách ale na znázornenie vieme použit' vždy len dve vybrané kategórie. Najlepšiu skupinu tvorí $18,2 \%$ jednotiek, najhoršia skupina obsahuje $11,9 \%$ zaradených jednotiek a v strede sa nachádza $70 \%$ všetkých jednotiek.

Výsledok zhlukovej analýzy sú znázornené na $O b r . \check{c} .3$ a $O b r . \check{c}$. 4. Jednotlivé zhluky obsahujú zaradených študentov podla ich hodnotenia. Skupinu s najlepším hodnotením tvorí 35,1\% jednotiek, najhoršia skupina obsahuje 11,3\% zaradených jednotiek. V strede grafu sa nachádza zvyšných 53,7\% jednotiek. 


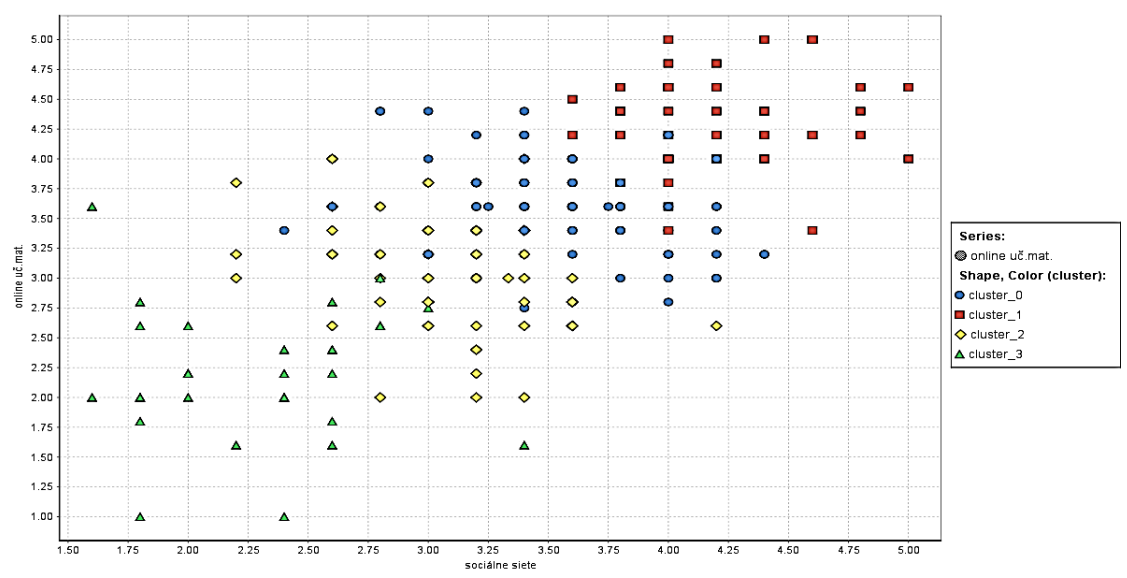

Obr. č. 3: Výsledok zhlukovania P6.

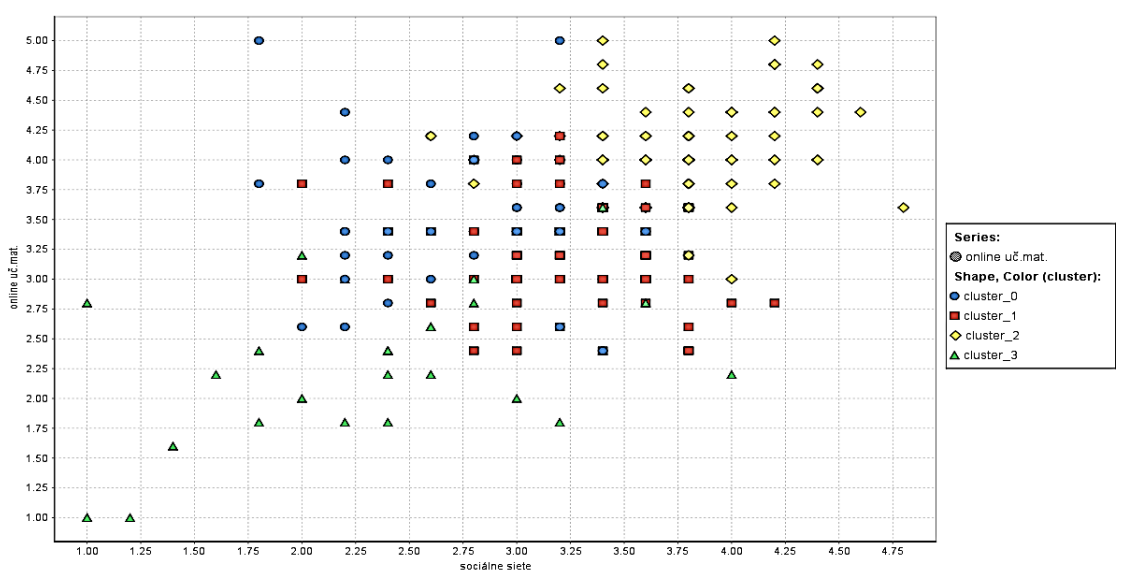

Obr. č. 4: Výsledok zhlukovania P7.

\section{Záver}

Prezentované výsledky predstavujú súhrn projektovej aktivity ako aj výsledky pedagogického bádania.

V rámci analýzy web-based aplikácií nebolo našim ciel’om hodnotit' aplikácie a ani klasifikovat' ich bodovým hodnotením, podl'a ktorého by sa vytvoril rebríček aplikácií, ale skôr charakterizovat' a hlbšie ich spoznat' $\mathrm{z}$ hl'adiska metodického spracovania a zároveň nájst' možnosti implementácie do pregraduálneho vzdelávania učitel'ov.

Výsledky dotazníka založené na sebareflexii respondentov ukázali, že v príprave budúcich pedagógov môžeme budovat' na dobrých zručnostiach študentov v práci s digitálnymi obrázkami a videom, a na komunikačných schopnostiach prostredníctvom sociálnych sietí. Potrebné je však venovat' väčšiu pozornost' k rozvíjaniu zručností študentov aj v oblasti práce s obrázkom a videom, napr. dobré predpoklady študentov 
v spracovaní videozáznamov sa dajú využit’ na tvorbu kvalitných video tutoriálov. V oblasti používania sociálnych sietí treba rozšrírit vedomosti študentov aj na ovládanie iných prvkov, ako je napr. social bookmarking. $V$ príprave budúcich učitel’ov potrebujeme študentom poskytnút' poznatky o online systémoch vhodných na riadenie učebného procesu, aby získali prehl'ad o týchto možnostiach a lepšie ovládali aj tvorbu online digitálneho obsahu.

Výsledky hodnotenia vyučujúcich pregraduálnej prípravy budúcich učitel’ov ukazujú, že aj vyučujúci sa musia permanentne vzdelávat' a zdokonal'ovat' sa v používaní nových digitálnych technológií. Podla názoru študentov učitelia hlavne zaostávajú v používaní sociálnych sietí na komunikáciu so študentmi, túto formu spoločnej práce $\mathrm{v}$ rámci vyučovacej činnosti pedagógovia ešte nevyužívajú v dostatočnej miere.

Na základe výsledkov prieskumu sme získali prehlad o silných a slabých stránkach digitálnych kompetencií študentov, ktoré môže byt' značne nápomocné a smerodajné pri inovácii foriem a metód vzdelávania, ktorého cielom popri skvalitnenia pregraduálnej prípravy učitel'ov je aj zatraktívnit' a zinteraktívnit' ich vysokoškolské štúdium.

Pod'akovanie: Tento príspevok vznikol s finančnou podporou projektu MŠVVaŠ SR, KEGA č.002UJS-4/2016.

\section{Literatúra}

Adcock, L. - Bolick, Ch. (2011). Web 2.0 tools and the evolving pedagogy of teacher education. Contemporary issues in technology and teacher education(11.2), s. 223-236. Albion, P. R. (2008). Web 2.0 in teacher education: Two imperatives for action. Computers in the Schools(25.3-4), s. 181-198.

Bolick, C., Berson, M., Coutts, C., \& Heinecke, W. (2003). Technology applications in social studies teacher education: A survey of social studies methods faculty. Contemporary Issues in Technology and Teacher Education, 3(3), s. 300-309. Cit. 06. 04 2018. Dostupné z: http://www.citejournal.org/vol3/iss3/socialstudies/article1.cfm

Brestenská, B. et al. (2014). Inkubátor inovatívnych učitel’ov prírodovedných predmetov na ZŠ a SS̆. In: Zbornik z medzinárodnej vedeckej konferencie Univerzity J. Selyeho 2014: "Vzdelávanie a veda na začiatku XXI. storočia" - Sekcie pedag. vied., s. 47-58.

Cantu, D. A. (2000). Technology integration in preservice history teacher education. Journal of the Association for History and Computing (3(2)), s. 1-19.

Grant, M. M. - Mims, C. (2009). Web 2.0 in teacher education: Characteristics, implications and limitations. Wired for learning: An educators guide to Web(2), s.343-360. Greenhow, C. (2007). What Teacher Education Needs to Know about Web 2.0: Preparing New Teachers in the 21st Century. Society for Information Technology and Teacher Education International Conference 2007, s. 1989-1992.

Heafner, T. L. - Friedman, A. M. (2008). Wikis and constructivism in secondary social studies: Fostering a deeper understanding. Computers in the Schools( 25.3-4), s. 288-302. Projekt: Inkubátor inovatívnych učitel’ov prírodovedných predmetov ZŠ a SŠ.(2014). Dostupné z: http://inkubatorucitelov.eskola.sk/.

Nisbet, R., Elder, J., Miner, G. (2009). Handbook of statistical analysis and data mining applications. Academic Press. Elsevier Inc.

UNESCO NA. (2012). Mobile Learning for Teachers in North America. UNESCO

Working Paper Series on Mobile Learning. Authored for UNESCO by

Fritschi,J. - Wolf, M.A. 